\title{
KELIMPAHAN BIVALVIA DI EKOSISTEM LAMUN PANTAI PUDING KABUPATEN BANGKA SELATAN
}

\author{
Bivalve Abundance at the Seagrass Ecology of Puding Beach, South Bangka Regency
}

\author{
Mutiara Febrina ${ }^{1}$, Wahyu Adi², Arief Febrianto ${ }^{3}$ \\ 1Jurusan Manajemen Sumberdaya Perairan FPPB-UBB, Balunijuk \\ 2 Jurusan Manajemen Sumberdaya Perairan FPPB-UBB, Balunijuk \\ ${ }^{3}$ Badan Perencanaan Pembangunan Penelitian dan pengembangan Daerah (BPPPPD), Bangka Selatan \\ Email korespondensi : mutiaraf44@gmail.com
}

Diterima September; disetujui Oktober; tersedia secara online November

\begin{abstract}
ABSTARCT
Puding Beach is administratively located in Pasir Putih Village, Tukak Sadai District, South Bangka Regency. As a coastal area, Puding Beach holds natural resource potential in both marine tourism and biota diversity. This study aims to analyze the abundance and distribution of bivalves and the seagrass beach community structure. This research was conducted in March 2018. The research method used was purposive sampling. Whereas for analysis of water quality characteristics and bivalve abundance, use main component analysis (Principle component analysis / PCA). The results showed that there were 6 species of seagrass and 7 species of bivalves at all stations. Each station I, II and III is dominated by the bivalve type Gafrarium tumidium with different seagrass species density. The highest density of seagrass species at stations I, II and III were Halodule uninervis (141 ind / m), Enhalus acoroides (7 ind / m) and Cymodocea serrulata (38 ind / m). Based on the analysis of main components can be seen the description of the condition to research location and can be seen the correlation between the existing bivalve abundance and the condition of the waters in all the research stations described in the F1-F2 factorial field. Important information on the main component axis is centered on the 2 main axes F1 (82.38\%) and F2 (4.62\%) of the total percentage. Bivalvia distribution analysis at Puding Beach is uniform and clustered based on habitat characteristics and environmental parameters that influence the life of bivalves.
\end{abstract}

Keywords: Bivalvia, seagrass, South Bangka

\section{PENDAHULUAN}

\subsection{Latar Belakang}

Pantai Puding secara administratif terletak di Desa Pasir Putih Kecamatan Tukak Sadai Kabupaten Bangka Selatan. Sebagai daerah pesisir, Pantai Puding menyimpan potensi sumberdaya alam baik di bidang pariwisata bahari maupun keanekaragaman biota. Salah satu sumberdaya di perairan tersebut yaitu ekosistem lamun dan bivalvia. Ekosistem lamun merupakan salah satu ekosistem yang mempunyai produktivitas primer yang relatif tingi (Riniatsih \& Munasik, 2017). Padang lamun adalah salah satu ekosistem produktif yang memiliki fungsi ekologi sebagai tempat pemijahan, perlindungan, habitat, serta pengasuhan bagi biota ekonomis penting. Bivalvia merupakan salah satu biota yang berasosiasi dengan ekosistem padang lamun. Bivalvia salah satu biota perairan yang banyak di minati oleh masyarakat, dagingnya yang kenyal dan cukup mudah untuk di dapat (Allifah, 2018). Bivalvia juga memiliki nilai ekonomis, misalnya cangkang bivalvia dapat dimanfaatkan sebagai bahan kerajinan (cinderamata).

Ekosistem lamun dan bivalvia salah satu sumberdaya laut yang ada di Pantai Puding dan cukup potensial serta perlu di jaga kelestariannya. Mengingat pentingnya manfaat dari ekosistem lamun dan bivalvia, serta belum adanya informasi mengenai kelimpahan bivalvia di ekosistem lamun Pantai Puding dan belum adanya pemanfaatan secara optimal serta berkelanjutan terhadap bivalvia di peraian tersebut, maka perlu di lakukan penelitian sebagai data awal dan data pendukung penelitian selanjunya.

\subsection{Tujuan}

Adapun tujuan dari penelitian ini adalah :

1. Menganalisis kelimpahan bivalvia di ekosistem lamun Pantai Puding Kabupaten Bangka Selatan.

2. Menganalisis struktur komunitas lamun di Pantai Puding

3. Menganalisis sebaran dan keterkaitan bivalvia dengan parameter perairan di ekosistem lamun Pantai Puding Kabupaten Bangka Selatan.

\subsection{Manfaat}

Adapun manfaat dari penelitian ini adalah:

1. Memberikan informasi mengenai kelimpahan dan sebaran bivalvia di ekosistem padang lamun Perairan Puding Kabupaten Bangka Selatan. 
2. Memberikan informasi tentang kajian dasar dan data awal dalam pengembangan metode riset di masa depan terkait kelimpahan bivalvia di ekosistem lamun Perairan Puding Kabupaten Bangka Selatan.

\section{METODE PENELITIAN}

\subsection{Waktu dan Tempat}

Penelitian ini di laksanakan pada bulan Maret 2018 di Pantai Puding Desa Pasir Putih Kabupaten Bangka Selatan. Identifikasi sampel di lakukan di Laboratorium Manajemen Sumberdaya Perairan, Fakultas Pertanian Perikanan dan Biologi, Universitas Bangka Belitung. Peta lokasi penelitian dapat di lihat pada Gambar 1.

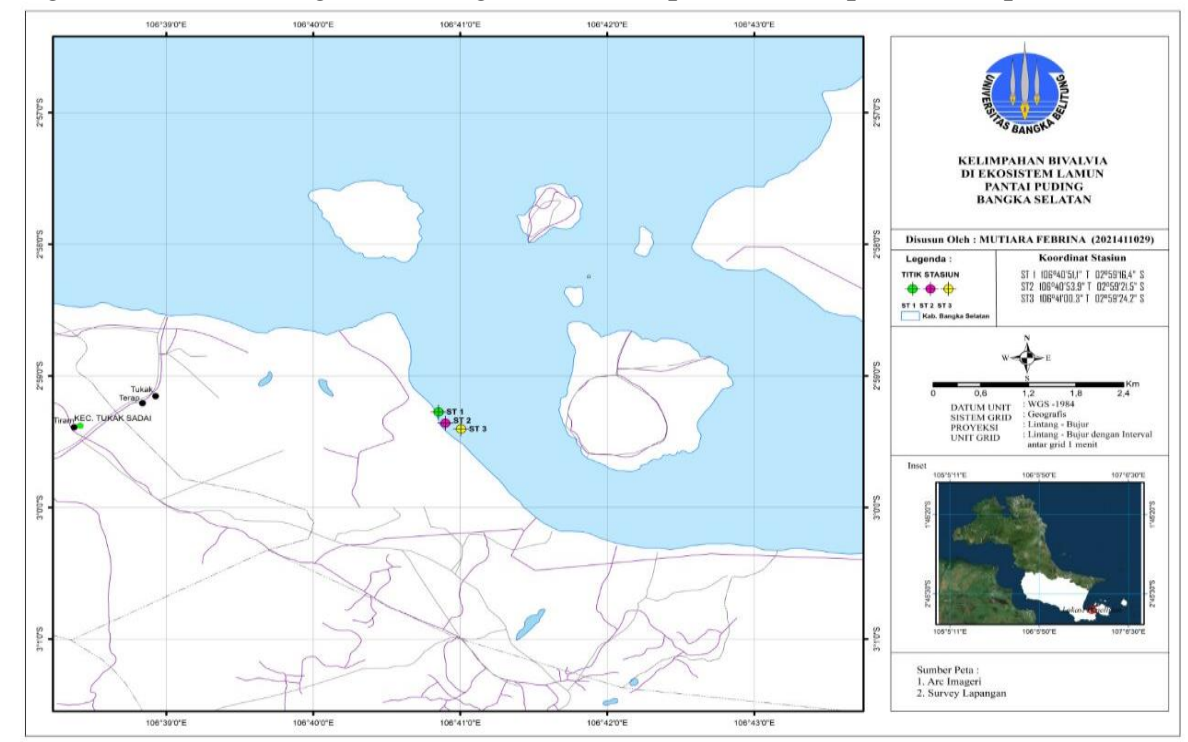

Gambar 1. Peta lokasi penelitian

\subsection{Alat dan Bahan}

Alat dan bahan yang di gunakan pada saat pengambilan data yaitu : termometer, hidro salinity, bola arus stopwatch, Secchi disk, botol sampel (1,5 liter), Sieve Shaker, Gps, kamera underwater, alat tulis, rool meter, transek Kuadrat $(1 \times 1$ meter $)$, core sampler $(30 \mathrm{~cm})$, tali rapiah, alkohol $75 \%$ dan plastik sample.

\subsection{Metode Pengambilan Data}

\subsubsection{Penentuan Titik Stasiun}

Penentuan stasiun pengamatan menggunakan metode purposive sampling di mana lokasi sampling di tentukan berdasarkan pertimbangan tertentu oleh peneliti (Fachrul, 2007). Pembagian stasiun dapat di lihat pada Tabel 1.

Tabel 1. Titik Pembagian Stasiun Pengambilan Data

\begin{tabular}{|c|c|c|}
\hline Stasiun & Titik Koordinat & Keterangan \\
\hline I & $106^{\circ} 40^{\prime} 51,1^{\prime \prime}$ BT dan $02^{\circ} 59^{\prime} 16,4^{\prime \prime} \mathrm{LS}$ & $\begin{array}{l}\text { Bagian sebelah kiri Pantai Puding, berdekatan dengan } \\
\text { mangrove dan di dominasi oleh jenis lamun Halodule } \\
\text { uninervis }\end{array}$ \\
\hline II & $106^{\circ} 40^{\prime} 53,9^{\prime \prime}$ BT dan $02^{\circ} 59^{\prime} 21,5^{\prime \prime} \mathrm{LS}$ & $\begin{array}{l}\text { Bagian tengah pantai Puding, di depan dermaga dan } \\
\text { berdekatan dengan perahu-perahu nelayan (aktivitas } \\
\text { nelayan) yang di dominasi oleh lamun yang berdaun } \\
\text { besar yaitu Enhalus acoroides }\end{array}$ \\
\hline III & $106^{\circ} 41^{\prime} 00,3^{\prime \prime}$ BT dan $02^{\circ} 59^{\prime} 24,2^{\prime \prime} \mathrm{LS}$ & $\begin{array}{l}\text { Bagian kanan Pantai Puding, berhadapan dengan Pulau } \\
\text { Tinggi yang di dominasi oleh jenis Cymodocea } \\
\text { serrulata }\end{array}$ \\
\hline
\end{tabular}

\subsubsection{Pengambilan Data Lamun}

Pengambilan sampel lamun di lakukan dengan menggunakan teknik gasir transek (line transect) modifikasi dari Fachrul (2007) dan KEPMENLH No. 200 Tahun 2004. Garis transek di tarik sepanjang 50 meter dengan arah tegak lurus garis pantai ke arah laut. Pada masing-masing transek di letakkan plot berukuran 1x1 meter dengan jarak antar plot 10 meter. Transek 1x1 meter di gunakan untuk meminimalisir waktu pengambilan data dan cakupan data yang di ambil banyak terwakili.

\subsubsection{Pengambilan Data dan Identifikasi Bivalvia}

Data bivalvia di ambil di dalam plot berukuran 1 meter x 1 meter yang di lakukan pada saat air surut. Pengambilan data bivalvia di ambil secara manual dengan tangan untuk contoh bivalvia yang terlihat, sedangkan yang membenamkan diri di ambil menggunakan core sampler dengan luas $0,0081 \mathrm{~m}^{2}$ secara acak sebanyak 5 kali (Setyobudiandi, et al., 2009) dengan kedalaman $30 \mathrm{~cm}$. Untuk memisahkan substrat dengan sampel bivalvia 
menggunakan alat bantu berupa saringan kawat. Identifikasi bivalvia di lapangan menggunakan metode visual sampling (pengamatan secara langsung) yakni pengambilan foto pada setiap plot. Identifikasi sampel bivalvia menggunakan metode morforistik. Metode morforistik adalah metode dengan melihat struktur morfologi (bentuk luar seperti: bentuk cangkang, warna, dan ukuran) dari bivalvia (Dharma, 2005).

\subsection{Pengukuran Parameter Lingkungan pada Ekosistem Lamun}

Pengukuran parameter lingkungan di lakukan dengan dua cara yaitu pengukuran secara langsung (in situ) dan pengukuran secara tidaka langsung (ex situ). Untuk pengukuran suhu, salinitas, kecepatan arus, kecerahan, TSS, pH dan DO di ambil pada saat air laut pasang, sedangkan untuk substrat di ambil pada saat air laut surut bersamaan dengan pengambilan data lamun dan bivalvia.

\subsection{Analisa Data}

3.2.1 Struktur Komunitas Bivalvia

3.2.1.1 Kelimpahan

Kelimpahan spesies adalah jumlah individu persatuan luas (Brower \& Zar, 1997).

Keterangan:

$$
D=\frac{N_{i}}{A}
$$

D : Kelimpahan individu spesies ke-i (ind/m2)

$\mathrm{Ni} \quad$ : Jumlah individu spesies ke-i

A : Luas bukaan mulut core sampler $\left(\mathrm{m}^{2}\right)$

\subsubsection{Keanekaragaman}

Keanekaragaman spesies di sebut juga heterogenan spesies yang dapat menggambarkan struktur komunitas dengan perhitungan menggunakan rumus Shannon-Wiener (Odum 1993).

Keterangan :

$$
H^{\prime}=\sum_{i=1}^{s} P i \log _{2} P i
$$

H' : Indeks keanekaragaman spesies

$\mathrm{Pi} \quad$ : Jumlah individu spesies ke-i terhadap jumlah individu total (ni/N)

$\mathrm{N} \quad$ : Jumlah total individu semua spesies

Penentuan kriteria :

$\mathrm{H}^{\prime}<3,32 \quad$ : Keanekaragaman jenis rendah, tekanan ekologi kuat

$3.32<\mathrm{H}^{\prime}<9.97 \quad$ : Keanekaragaman jenis sedang, tekanan ekologi sedang

H’>9.97 :Keanekaragaman jenis tinggi, terjadi keseimbangan ekositem

\subsubsection{Keseragaman}

Indeks keseragaman adalah komposisi individu tiap spesies yang terdapat dalam suatu komunitas (Odum, 1993) dengan perhitungan sebagai berikut:

Keterangan :

$$
E=\frac{H^{\prime}}{H_{\text {maks }}}
$$

E : Indeks keseragaman

H' : Indeks keanekaragaman Shannon-Wiener

$\mathrm{H}$ maks : Keanekaragaman maksimum $\left(\log _{2} \mathrm{~S}\right)$

S : Jumlah spesies

Dengan kriteria:

$\mathrm{E}<0.4 \quad:$ Keseragaman rendah

$0.4<\mathrm{E}<0.6 \quad:$ Keseragaman sedang

E $>0.6 \quad$ : Keseragaman Tinggi

\subsubsection{Dominansi}

Indeks dominansi digunakan untuk mengetahui ada tidaknya spesies yang dominansi pada komunitas, digunakan indeks dominansi Simpson (Odum 1993, dalam Akhrianti , 2014):

Keterangan :

$$
C=\sum_{i=1}^{n i}(p i)^{2}
$$

D : Indeks dominansi Simpson

pi : Jumlah individu spesies ke -i per jumlah individu total

Nilai indeks dominan berkisar antara 0-1. Apabila nilai indeks dominansi mendekati 0, maka tidak ada spesies yang mendominasi dan diikuti dengan indeks keseragaman yang besar. Dan sebaliknya apabila indeks dominansi mendekati 1, berarti ada salah satu spesies yang mendominasi dan nilai keseragaman semakin kecil. 


\subsubsection{Pola Sebaran Jenis}

Untuk mengetahui pola sebaran jenis suatu organisme pada suatu habitat di gunakan Indeks Sebaran Morisita (Soegianto, 1994 dalam Samir, 2016) sebagai berikut :

Keterangan :

Id = Indeks Sebaran Morisita

$\sum \mathrm{Xi}=$ Jumlah individu dalam setiap titik kuadrat

$$
\frac{\mathrm{Id}=\sum \mathrm{Xi}^{2}-\mathrm{N}}{\mathrm{N}(\mathrm{n}-1)}
$$

$\sum \mathrm{Xi}^{2}=$ Jumlah individu di kuadratkan di setiap titik kuadrat

$\mathrm{n} \quad=$ Jumlah petak pengambilan contoh

$\mathrm{N}=$ Jumlah total plot pada pengambilan data

Adapun persamaan Indeks Sebaran Morisita yaitu :

Id=1 acak $\quad I d<1$ Seragam $\quad I d>1$ Mengelompok

Di lakukan perhitungan dua kriteria indeks sebaran morisita yaitu indeks keseragaman dan indeks pengelompokkan dengan menggunakan persamaan berikut ( Krebs, 1998 dalam Supratman, 2015) :

$$
M u=\frac{\mathrm{x}^{2} 0,975-\mathrm{n}+\sum \mathrm{xi}}{(X i)-1}
$$

$$
M c=\frac{\mathrm{x}^{2} 0,025-\mathrm{n}+\sum \mathrm{xi}}{(X i)-1}
$$

Keterangan :

$\mathrm{Mu} \quad=$ Indeks keseragaman

Mc = Indeks pengelompokkan

$\mathrm{n} \quad=$ Jumlah individu dalam setiap kuadrat

$x^{2} 0,025=$ Nilai khi kuadrat tabel $(\mathrm{db}=\mathrm{n}-1)$

$x^{2} 0,975=$ Nilai khi kuadrat tabel $(\mathrm{db}=\mathrm{n}-1)$

\subsubsection{Indeks Nilai Penting (INP)}

INP digunakan untuk menghitung dan menduga secara keseluruhan dari peranan satu spesies di dalam suatu komunitas. Semakin tinggi nilai INP suatu spesies relatif terhadap spesies lainnya maka semakin tinggi peranan spesies tersebut pada komunitasnya. Rumus yang digunakan dalam menghitung INP adalah (Brower \& Zar, 1998) :
Keterangan
INP
Rdi
Rfi
Rci

$$
I N P=R F_{i}+R C_{i}+R D_{i}
$$

\subsubsection{Keterkaitan Kelimpahan Bivalvia dengan Parameter Perairan di Ekosistem Lamun Pantai puding}

Analisis dalam menentukan keterkaitan kelimpahan bivalvia dengan parameter perairan ekosistem lamun Pantai Puding antar stasiun di gunakan suatu pendekatan analisis statistik multivariate yang di dasarkan pada pada analisis komponen utama (Principal Component Analyisis) ( Bengen, 2000). Analisis komponen utama (PCA) merupakan metode deskriptif yang bertujuan mempresentasikan dalam bentuk grafik, informasi mana yang terdapat dalam suatu matrik data. Matrik data yang di maksud adalah terdiri dari stasiun pengamatan sebagai individu stastistik deskriptif yang menggambarkan keterkaitan parameter lingkungan dengan stasiun pengamatan. Data dari parameter lingkungan yang di masukkan seperti suhu, salinitas, oksigen terlarut, kecerahan, pH, TSS dan substrat. Dengan demikian matriks data ini merupakan tabel kontingensi bivalvia dengan parameter lingkungan antar stasiun pengamatan. Analisi PCA di analisis dengan bantuan software statistik 6.0.

\section{HASIL DAN PEMBAHASAN}

\subsection{Hasil}

4.1.1 Struktur Komunitas Bivalvia

4.1.1.1 Kelimpahan Bivalvia

Kelimpahan adalah jumlah individu suatu spesies di bagi luas area pengamatan. Hasil kelimpahan bivalvia tertingi terdapat pada spesies Gafrarium tumidum dengan jumlah 458 ind dan jenis Anadara antiquata dengan jumlah 110 ind. Kelimpahan bivalvia dapat di lihat pada Tabel 2.

Tabel 2. Kelimpahan Bivalvia di Ekosistem Lamun

\begin{tabular}{lcccc}
\hline \multirow{1}{*}{ Spesies } & \multicolumn{2}{c}{ Kelimpahan $\left(\right.$ Ind $\left./ \mathbf{m}^{3}\right)$} & \multirow{2}{*}{ Jumah Total } \\
\cline { 2 - 3 } & ST I & ST II & ST III & \\
\hline Family Arcidae & 105 & 5 & 0 & 110 \\
Anadara antiquata & \multicolumn{4}{c}{} \\
\hline Family Placunidae & & & \\
\hline
\end{tabular}




\begin{tabular}{lcccc}
\hline Placuna placenta & 14 & 0 & 9 & 23 \\
\hline Family Tellinidae & 9 & 9 & 5 & 23 \\
Tellina remies & & & & \\
\hline Family Veneridae & 32 & 14 & 14 & 60 \\
Anomalocardia squamosa & 0 & 14 & 0 & 14 \\
Dosinia victoriae & 247 & 110 & 101 & 458 \\
Gafrarium tumidum & 5 & 0 & 9 & 14 \\
Placemen tiara & 412 & 152 & 138 & \\
\hline Jumlah Individu & & &
\end{tabular}

*Keterangan: ST (Stasiun)

\subsubsection{Indeks Keanekaragaman, Keseragaman dan Dominansi}

Nilai indeks keanekaragaman, keseragaman dan dominansi bivalvia dapat di lihat pada Tabel 3.

Tabel 3. Nilai Keanekaragaman (H'), Keseragaman (E), dan Dominansi (C)

\begin{tabular}{cccc}
\hline Stasiun & Indeks $\left(\mathbf{H}^{\prime}\right)$ & Indeks $(\mathbf{E})$ & Indeks $(\mathbf{C})$ \\
\hline I & 1,102 & 0,615 & 0,433 \\
II & 0,893 & 0,555 & 0,580 \\
III & 0,932 & 0,579 & 0,558 \\
\hline
\end{tabular}

\subsubsection{Pola Sebaran Jenis}

Nilai pola sebaran bivalvia di ekosistem lamun Pantai Puding bersifat seragam dan mengelompok. Pola sebaran jenis bivalvia dapat di lihat pada Tabel 4.

Tabel 4. Pola Sebaran Jenis Bivalvia di Ekosistem Lamun Pantai Puding

\begin{tabular}{lcc}
\hline \multicolumn{1}{c}{ Spesies } & Id & Pola Sebaran \\
\hline $\begin{array}{l}\text { Family Arcidae } \\
\text { Anadara antiquata }\end{array}$ & 1,804 & Mengelompok \\
$\begin{array}{l}\text { Family Tellinidae } \\
\text { Tellinia remies }\end{array}$ & 1,200 & Mengelompok \\
$\begin{array}{l}\text { Family Placunidae } \\
\text { Placuna placenta }\end{array}$ & & Mengelompok \\
$\begin{array}{l}\text { Family Veneridae } \\
\text { Anomalocardia squamosa }\end{array}$ & 2,400 & Seragam \\
Dosinia victoriae & & Mengelompok \\
Gafrarium tumidum & 0,692 & Seragam \\
Placemen tiara & 6,000 & Mengelompok \\
\hline
\end{tabular}

4.1.2 Struktur Komunitas Lamun

4.1.2.1 Kepadatan Jenis, Frekuensi Jenis, dan Penutupan Jenis Lamun

Kepadatan jenis lamun di pengaruhi oleh jumlah tegakan suatu jenis lamun pada suatu luasan tertentu. Kepadatan jenis lamun dapat di lihat pada Gambar 2.

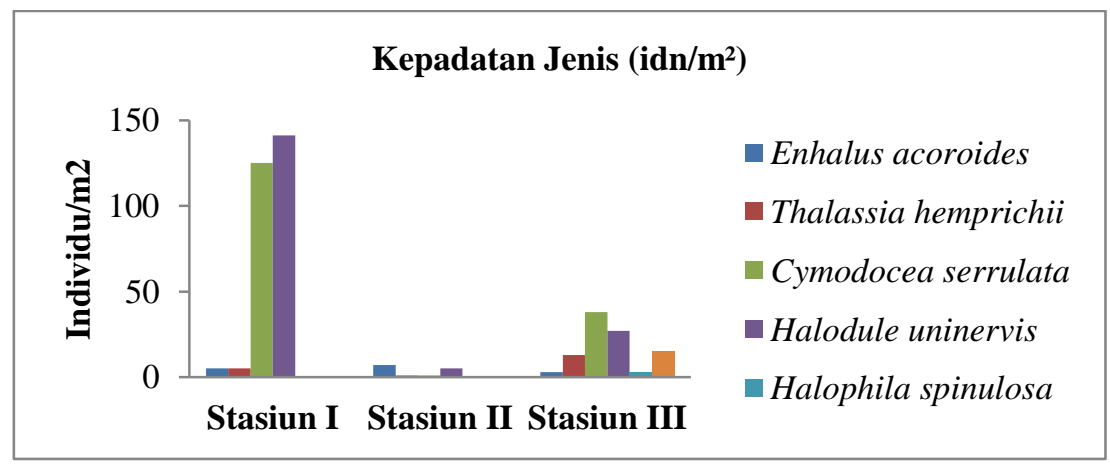

Gambar 2. Kepadatan Jenis Lamun

Lamun Halodule uninervis mempunyai kepadatan tertinggi pada stasiun I dengan nilai $141 \mathrm{ind} / \mathrm{m}^{2}$. Untuk stasiun II kepadatan tertinggi oleh lamun Enhalus acoroides dengan nilai $7 \mathrm{ind} / \mathrm{m}^{2}$. Stasiun III kepadatan tertinggi 
adalah jenis Cymodocea serrulata dengan nilai $38 \mathrm{ind} / \mathrm{m}^{2}$. Frekuensi jenis lamun adalah peluang suatu jenis ditemukannya lamun dalam petak contoh yang di amati. Frekuensi jenis dapat di lihat pada Gambar 3.

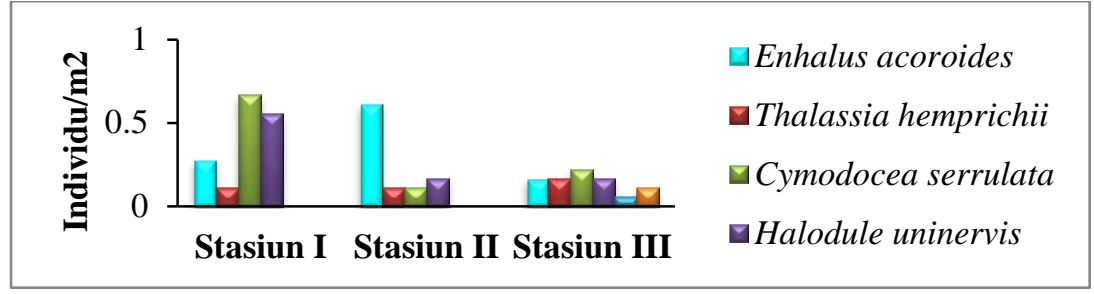

Gambar 3. Frekuensi Jenis lamun

Frekuensi lamun tertinggi terdapat pada stasiun I jenis Cymodocea serrulata dengan nilai 0,667 ind $/ \mathrm{m}^{2}$. Pada stasiun II nilai frekuansi tertinggi yaitu jenis lamun Enhalus acoroides dengan nilai 0,611 ind $/ \mathrm{m}^{2}$, sedangkan pada stasiun III frekuensi tertinggi sama dengan stasiun I adalah jenis Cymodocea serrulata dengan nilai $0,222 \mathrm{ind} / \mathrm{m}^{2}$. Penutupan jenis lamun adalah perbandingan penutupan antara individu spesies ke-i dengan jumlah total penutupan seluruh jenis. Penutupan jenis lamun stasiun I, II dan III dapat di lihat pada Gambar 4, 5 dan 6.

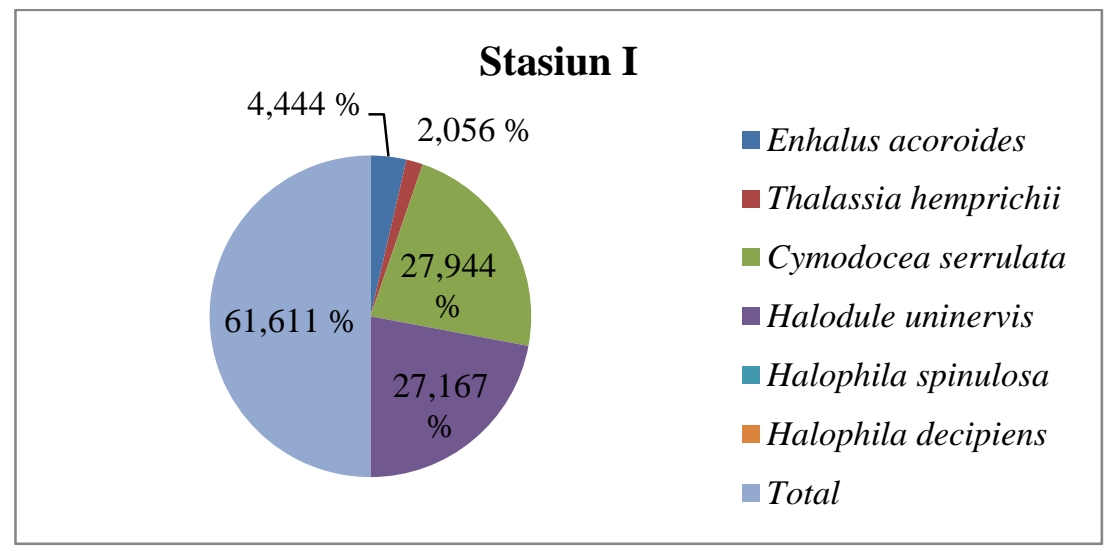

Gambar 4. Penutupan Jenis Lamun Stasiun I

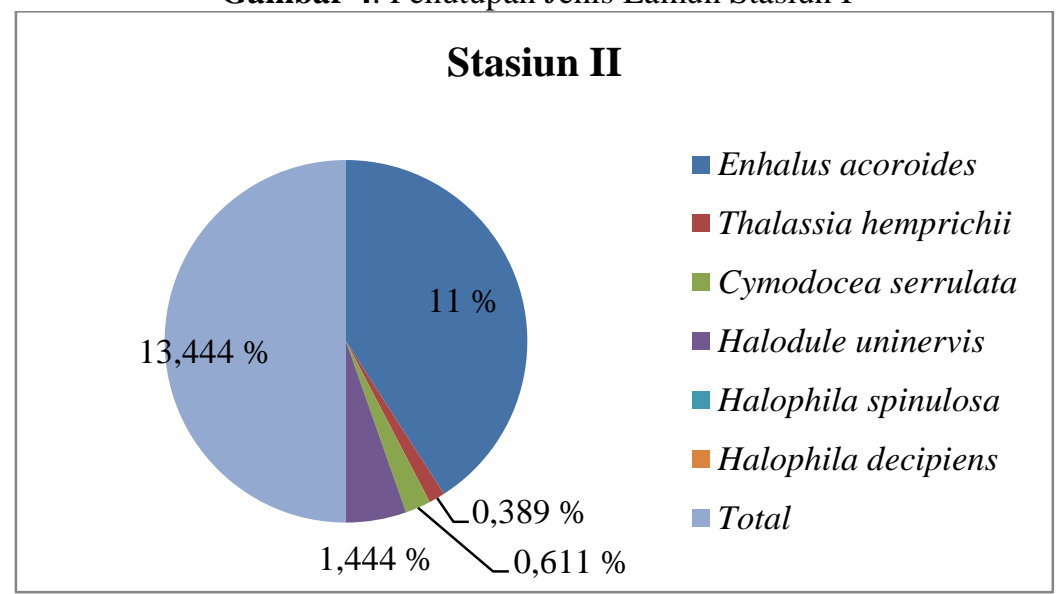

Gambar 5. Penutupan Jenis Lamun Stasiun II 


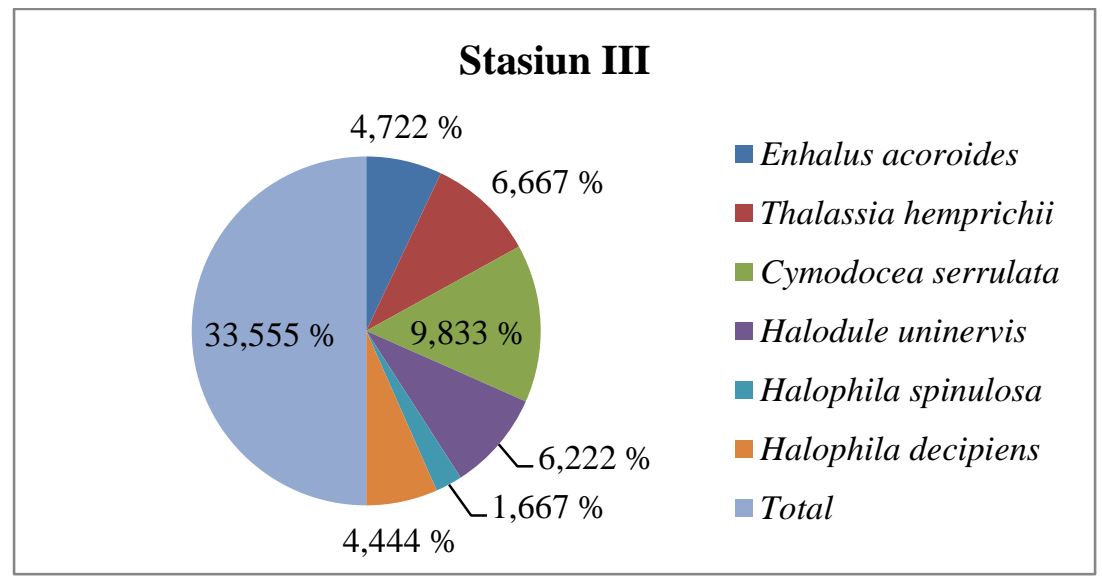

Gambar 6. Penutupan Jenis Lamun Stasiun III

Penutupan jenis lamun tertinggi pada stasiun I adalah Cymodocea serrulata dengan nilai 27,944\%. Pada stasiun II penutupan jenis tertinggi yaitu Enhalus acoroides dengan nilai 11\%, sedangan pada stasiun III kembali lagi nilai penutupan jenis tertinggi adalah Cymodocea serrulata dengan nilai 9,833\%.

\subsubsection{Indeks Nilai Penting}

INP digunakan untuk menghitung dan menduga secara keseluruhan dari peranan satu spesies didalam suatu komunitas. Indeks Nilai Penting dapat di lihat pada Gambar 7.

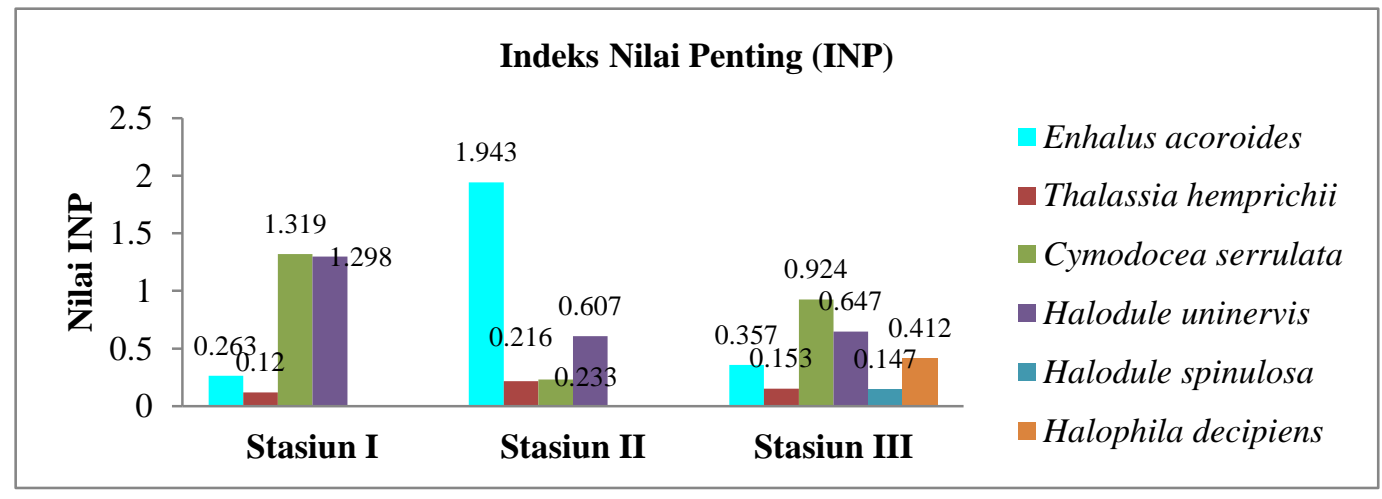

Gambar 7. Indeks Nilai Penting Lamun

Nilai INP tertinggi pada stasiun I yaitu jenis Cymodocea rotundata yaitu 1,319 dan nilai INP terendah adalah jenis Thalassia hemprichii yaitu 0,12. Stasiun II nilai INP tertinggi yaitu jenis Enhalus acoroides yaitu 1,943 dan nilai INP terendah adalah jenis Thalassia hemprichii yaitu 0,216. Sedangkan pada stasiun III nilai INP tertinggi yaitu jenis Cymodocea rotundata yaitu 0,924 dan nilai INP terendah adalah jenis Halodule spinulosa dengan nilai 0,147.

\subsubsection{Parameter Lingkungan Perairan}

Parameter fisika-kimia perairan yang di ukur meliputi suhu, salinitas, pH, TSS, kecepatan arus, kecerahan, DO dan substrat. Adapun kondisi parameter fisika-kimia ekosistem lamun pantai puding dapat di lihat pada Tabel 5.

Tabel 5. Parameter Fisika-Kimia Perairan pada Ekosistem Lamun Pantai puding

\begin{tabular}{lcccc}
\hline \multirow{2}{*}{ Parameter } & \multirow{2}{*}{ Satuan } & \multicolumn{3}{c}{ Stasiun Pengamatan } \\
\cline { 3 - 5 } & & Stasiun I & Stasiun II & Stasiun III \\
\hline Kecerahan & $\mathrm{Cm}$ & 0,783 & 0,31 & 0,333 \\
Suhu & ${ }^{\circ} \mathrm{C}$ & 29 & 30 & 29,667 \\
Kecepatan Arus & $\mathrm{m} / \mathrm{s}$ & 0,03 & 0,025 & 0,026 \\
Salinitas & $\mathrm{Ppt}$ & 27 & 30 & 29 \\
DO & $\mathrm{mg} / \mathrm{l}$ & 7,2 & 6,7 & 7,2 \\
pH & - & 6 & 6 & 5,7 \\
TSS & $\mathrm{mg} / 1$ & 507,3 & 474,7 & 487,7 \\
\hline
\end{tabular}




\subsubsection{Tekstur Substrat}

Analisa tekstur substrat di Laboratorium menunjukkan substrat dasar berupa pasir terdapat pada ketiga stasiun ekosistem lamun Pantai Puding. Hasil analisa tekstur substrat dapat di lihat pada Tabel 6.

Tabel 6. Tekstur Substrat pada Ekosistem Lamun Pantai Puding

\begin{tabular}{cccc}
\hline \multirow{2}{*}{ Stasiun } & \multicolumn{3}{c}{ Tekstur Substrat } \\
\cline { 2 - 4 } & Pasir (\%) & Lanau dan Lempung (\%) & Tipe Substrat \\
\hline I & 87,27 & 12,72 & Pasir \\
II & 85,5 & 14,49 & Pasir \\
III & 86,05 & 13,94 & Pasir \\
\hline
\end{tabular}

\subsubsection{Keterkaitan Kelimpahan Bivalvia dengan Parameter Perairan Ekosistem Lamun Pantai puding}

Analisa beberapa variabel lingkungan yang dimasukkan dalam analisis komponen utama (Principal Component Analysis) meliputi suhu, salinitas, $\mathrm{pH}$, kecepatan arus, DO, TSS, substrat, kecerahan, kepadatan lamun, dan kelimpahan bivalvia. Hasil analisis dapat di lihat pada Gambar 8.

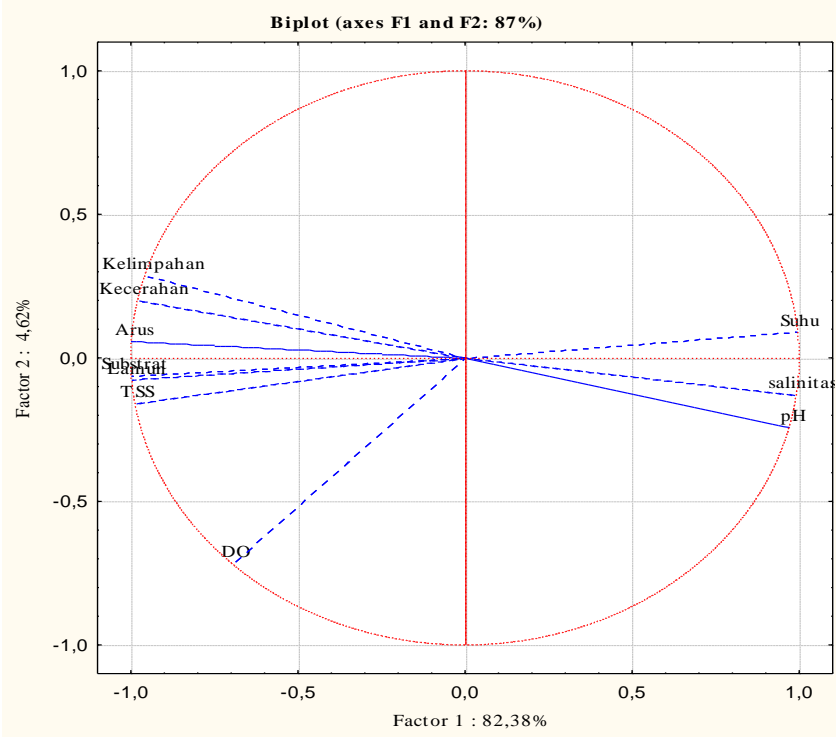

Gambar 8. Diagram hasil analisis komponen utama (PCA)

\subsection{Pembahasan}

\subsubsection{Struktur Komunitas Bivalvia}

\subsubsection{Kelimpahan Bivalvia}

Hasil bivalvia yang di temukan pada penelitian ini sebanyak 7 (tujuh) spesies dari 4 (empat) family. Jenis bivalvia yang memiliki kelimpahan tertinggi dan di dominansi oleh Gafrarium tumidum, Anadara antiquata dan Anomalocardia squamosa, namun jenis yang paling mendominansi dari semua stasiun yaitu Gafrarium tumidum. Hal tersebut di karenakan kondisi lamun yang rapat biasanya merupakan habitat yang paling baik untuk berlindung dan mencari makan bagi berbagai jenis organisme laut salah satunya bivalvia jenis Gafrarium tumidum (Riniatsih \& Munasik, 2017 ; Islami, 2014). Kelimpahan bivalvia tertinggi terdapat pada stasiun I yang di dominansi oleh jenis Gafrarium tumidum sebesar $247 \mathrm{ind} / \mathrm{m}^{2}$ dan di temukan pada semua stasiun pengamatan. Hal ini mengindikasikan bahwa Gafrarium tumidum cenderung lebih menguasai ruang serta mampu bertahan hidup pada semua stasiun yang di amati. Berdasarkan pernyataan (Setyobudiandi, 1997) dalam (Arisma, 2017) bahwa jenis substrat sangat menentukan kelimpahan dan komposisi hewan benthos serta di pengaruhi oleh lingkungan perairan dan kondisi habitat yang cocok untuk kehidupan spesies ini. Kelimpahan pada stasiun II dan III juga di dominasi oleh jenis Gafrarium tumidum, namun jumlah individunya lebih banyak pada stasiun I. Melimpahnya Gafrarium tumidum pada semua stasiun di karenakan spesies ini menyukai habitat pasir kasar yang cocok untuk memperoleh makanan dengan cara filter feeder. Hal ini juga mengindikasikan bahwa habitat di Pantai Puding cocok untuk pertumbuhan spesies ini.

\subsubsection{Indeks Keanekaragaman, Keseragaman dan Dominans}

Nilai indeks keanekaragaman bivalvia di Pantai Puding berkisar antara 0,893-1,102. Nilai keanekaragaman tertinggi terdapat pada stasiun I yaitu 1,102. Namun keanekaragaman bivalvia pada Pantai Puding di kategorikan rendah 
berdasarakan kriteria Shannon-Wiener yang di artikan bahwa komunitas bivalvia di Pantai Puding dalam tekanan ekologi kuat. Nilai keanekaragaman terendah terdapat pada stasiun II dengan nilai 0,893, hal tersebut di karenakan adanya perbedaan karakteristik pada masing-masing stasiun. Tinggi rendahnya nilai indeks keanekaragaman bukan hanya tergantung pada perbedaan karakteristik atau tergantung pada jumlah jenis yang di temukan, namun juga ditentukan oleh kesamarataan populasi dalam komunitas (Nurdin et al., 2008).

Nilai indeks keseragaman bivalvia berkisar antara 0,555-0,615 menunjukkan tingkat keseragaman sedang hingga tinggi. Berdasarkan kriteria Shannon-Wiener yang di gunakan menunjukkan adanya jumlah individu yang terkonsentrasi pada satu atau beberapa jenis. Hal tersebut dapat di artikan bahwa di lokasi Pantai Puding terdapat satu atau beberapa spesies yang jumlahnya relatif banyak, sedangkan beberapa spesies lainnya memiliki jumlah yang relatif sedikit. Semakin kecil nilai keseragaman mengindikasikan bahwa penyebaran jenis tidak merata. Nilai indeks keseragaman tertinggi terdapat pada stasiun I dengan nilai 0,615, hal ini menggambarkan bahwa pada stasiun I terjadi adanya keseimbangan ekologis pada suatu komunitas, di mana semakin tinggi nilai keseragaman kualitas lingkungan semakin baik dan cocok dengan kehidupan bivalvia, meskipun tetap terjadi persaingan antar spesies dalam mendapatkan makanan (Zarkasyi et al., 2016).

Nilai indeks dominansi bivalvia berkisar antara 0,433-0,580. Hal ini mencerminkan bahwa adanya spesies yang paling mendominasi. Nilai indeks dominansi tertinggi terdapat pada stasiun II dengan nilai 0,580, hal tersebut mengartikan bahwa pada stasiun II nilai keseragamannya rendah. Berdasarkan kriteria Dominansi Simpson yang di gunakan, menyatakan bahwa apabila indeks dominansi mendekati 1, berarti ada salah satu spesies yang mendominasi dan nilai keseragaman semakin kecil. Hasil dari pengamatan di peroleh bahwa jenis Gafrarium tumidum pada setiap stasiun di temukan dalam jumlah yang paling banyak di bandingkan dengan jenis lain. Hal ini di karenkan bahwa Gafrarium tumidum mampu hidup pada semua tipe substrat di Pantai Puding. Menurut (Kharisma et al., 2012), indeks dominansi digunakan untuk mengetahui jenis bivalvia yang mendominasi pada suatu komunitas dan untuk mengetahui pengaruh kualitas lingkungan terhadap komunitas suatu individu.

\subsubsection{Pola Sebaran Jenis}

Pola penyebaran bivalvia yang di peroleh pada saat penelitian memiliki pola penyebaran bersifat seragam dan mengelompok. Hasil penelitian menunjukkan bahwa sebaran bivalvia yang terlihat pada Tabel cenderung mengelompok (Id>1). Menurut (Werdiningsih, 2005) dalam (Zarkasyi et al., 2016), Pola dengan sebaran mengelompok adalah pola organisme atau biota di suatu habitat yang hidup berkelompok dalam jumlah tertentu. Pola penyebaran sangat khas pada setiap spesies dan jenis habitat. Penyebab terjadinya pola sebaran tersebut akibat dari adanya perbedaan respon terhadap habitat secara lokal. Pola penyebaran mengelompok dengan tingkat pengelompokkan yang bermacam-macam merupakan bentuk penyebaran yang paling umum terjadi, karena individu-individu dalam populasi cenderung membentuk kelompok dalam berbagai ukuran. Pola sebaran seragam terjadi karena adanya persaingan individu sehingga mendorong pembagian ruang hingga seragam (Odum, 1993). Pola penyebaran secara seragam di Pantai Puding di duga kondisi habitat yang cocok dengan jenis Gafrarium tumidum dan Anomalocardia squamosa yang menyukai substrat berpasir dalam memperoleh makanan, karena pada substrat tersebut tersedia sumber makanan untuk kehidupannya yang berasal dari tumpukan serasah lamun yang terbawa oleh arus kemudian mengendap pada substrat di dasar perairan.

\subsubsection{Struktur Komunitas Lamun}

Hasil penelitian menunjukkan jenis lamun yang di temukan sebanyak 6 (enam) jenis yaitu Enhalus acoroides, Thalassia hemprichii, Cymodocea serrulata, Halodule uninervis, Halodule spinulosa dan Halophila decipiens. Nilai kepadatan tertinggi terdapat pada stasiun I yaitu jenis Halodule uninervis sebesar $141 \mathrm{ind} / \mathrm{m}^{2}$. Sedangkan nilai kepadatan terendah terdapat pada stasiun II yaitu jenis Enhalus acoroides sebesar $7 \mathrm{ind} / \mathrm{m}^{2}$. Rendahnya kepadatan jenis Enhalus acoroides di karenakan habitat lamun di Pantai Puding tidak cocok untuk pertumbuhan dan kehidupannya. Menurut (Bengen, 2002) menyatakan bahwa Enhalus acoroides merupakan lamun yang tumbuh pada substrat berlumpur dari perairan keruh dan dapat membentuk jenis tunggal, sedangkan substrat di Pantai Puding yaitu substrat pasir hingga pasir berlumpur. Jenis Enhalus acoroides memiliki toleransi untuk perubahan suhu, salinitas dan jenis substrat lebih luas dibanding jenis lainnya (Zarkasyi et al., 2016). Pada stasiun II nilai kepadatan lamun memang rendah, dan jenis lamun yang di temukan juga relatif sedikit. Hal ini di duga karena adanya aktivitas manusia di daerah stasiun tersebut, misalnya aktivitas para nelayan yg melakukan penambatan kapal serta kegiatan bongkar muat hasil tangkapan. Hal ini sesuai dengan pendapat (Riniatsih \& Munasik, 2017) bahwa tekanan yang sering di alami oleh ekosistem padang lamun adalah adanya aktifitas masyarakat pesisir yang banyak memanfaatkan padang lamun sebagai tempat menangkap ikan dan sebagai jalur lalu lintas kapal nelayan.

Jenis lamun cymodocea serrulata memiliki nilai kepadatan tertinggi pada stasiun III yaitu $38 \mathrm{ind} / \mathrm{m}^{2}$. Tingginya nilai kepadatan jenis tersebut menandakan bahwa cymodocea serrulata mampu hidup pada substrat berpasir seperti di Pantai Puding, selain itu juga lamun jenis Cymodocea sp memiliki toleransi yang tinggi terhadap perubahan kondisi lingkungan (Suherman, 2012) dalam (arisma, 2017), meskipun nilai kepadatan yang paling tinggi yaitu Halodule uninervis. Hal ini di duga lamun jenis cymodocea serrulata dapat bersaing dengan baik dalam mendapatkan makanan untuk pertumbuhan hidupnya. Kepadatan lamun di Pantai Puding memiliki perbedaan nilai kepadatan yang cukup tinggi dari setiap stasiun pengamatan yang di lakukan.

Penutupan lamun tertinggi pada stasiun I dan III yaitu cymodocea serrulata dengan nilai 27,944\% dan 9,833\%. Tingginya penutupan lamun jenis ini berbanding terbalik dengan kerapatannya, namun nilai penutupan lamun dengan frekuensi berbanding lurus dengan di temukannya spesies yang sama. Hal ini di duga adanya penyebaran lamun yang 
sangat bervariasi tergantung pada topografi pantai dan pola arus pasang surut. Penutupan lamun yang rendah dapat ditemui pada daerah yang telah terganggu aktivitas manusia dan pada daerah alami mengalami penutupan yang tinggi (Kusumaatmaja et al., 2016). Penutupan lamun terendah terdapat pada stasiun II, dengan jumlah penutupan 13,444\%, memang benar karena adanya aktivitas para nelayan pada stasiun tersebut.

4.2.3 Keterkaitan Kelimpahan Bivalvia dengan Parameter Perairan Ekosistem Lamun Pantai puding

Berdasarkan analisis komponen utama dapat di ketahui gambaran kondisi lokasi penelitian dan dapat di lihat korelasi antara kelimpahan bivalvia yang ada dengan kondisi perairannya pada seluruh stasiun penelitian yang di gambarkan pada bidang faktorial F1-F2 Gambar 8. Informasi penting terhadap sumbu komponen utama terpusat pada 2 sumbu utama F1 $(82,38 \%)$ dan F2 (4,62\%) dari keseluruhan persentase ragam total. Pada Gambar 8 menunjukkan hubungan yang sama antara salinitas, $\mathrm{pH}$ dan suhu yaitu berkorelasi positif. Hasil pengukuran suhu pada lokasi penelitian pada setiap stasiun berkisar $29-30^{\circ} \mathrm{C}$ masih berada pada kisaran normal untuk kehidupan biota laut, sesuai standar baku mutu yang di tetapkan oleh Kementerian Lingkungan Hidup (2004) yakni antara $28^{\circ} \mathrm{C}-30^{\circ} \mathrm{C}$. Menurut (Islami, 2013) pada kenaikan suhu air yang lebih tinggi memberikan hasil pertumbuhan yang lebih baik daripada suhu yang lebih rendah, hal ini dapat di lihat dari hasil yang di peroleh pada stasiun II lebih banyak di bandingkan stasiun III. Untuk nilai $\mathrm{pH}$ pada setiap stasiun penelitian berkisar 5-6, cenderung bersifat asam. Namun masih dalam kisaran normal untuk kehidupan bivalvia di ekosistem lamun. Hal ini sesuai dengan pernyataan (Riniatsih \& Widianingsih, 2007) $\mathrm{pH}$ untuk kelangsungan hidup bivalvia berkisar antara $>5$ dan $>9$.

Faktor lingkungan fisika, kimia, maupun biologi memiliki pengaruh terhadap keberadaan suatu jenis makrozoobentos di daerah lamun. Bivalvia pada umumnya di temukan pada substrat dasar. Adanya vegetasi lamun mempengaruhi tinggi rendahnya kelimpahan bivalvia, karena sebagian dari jenis bivalvia pemakan detritus yang jatuh ke dasar perairan dan membusuk sebagai sumber makanan. Hal ini sesuai pernyataan (Herawati et al., 2017) bahwa kelimpahan dan keanekaragaman bivalvia hanya di tentukan 12\% oleh kerapatan lamun, sebaliknya $88 \%$ ditentukan oleh faktor lain, termasuk fisik kimia perairan.

Salinitas pada penelitian ini berkisar 27-30 ppt. Nilai ini masih dalam kisaran normal untuk kehidupan bivalvia. Hal ini seseuai pernyataan (Islami, 2013) bahwa salinitas optimum bagi kelangsungan hidup bivalvia yang dapat di toleransi hingga 31 ppt. Salinitas berpengaruh pada produksi, distribusi, lama hidup serta orientasi migrasi. Nilai TSS pada setiap stasiun penelitian berkisar 474,7-507,3 mg/l. Menurut (Akhrianti, 2014) kisaran nilai TSS antara $81 \mathrm{mg} / \mathrm{l}$ - $400 \mathrm{mg} / \mathrm{l}$ akan mempengaruhi kelangsungan hidup organisme bentik khususnya gastropoda dan bivalvia. Arus merupakan salah satu faktor yang mempengaruhi keberadaan suatu spesies. Pada penelitian ini nilai arus berkisar 0,025-0,03 m/s, arus yang di dapat relatif tenang. Pergerakan arus yang cukup lambat di daerah berpasir menyebabkan partikel-partikel halus mengendap dan melimpahnya detritus sebagai sumber makanan bagi bivalvia. Menurut Setyobudiandi (2004), kondisi arus dapat mempengaruhi penyebaran fraksi substrat.

Kecerahan berkorelasi negatif terhadap TSS, semakin tinggi nilai kecerahan maka semakin rendah nilai TSS dan sebaliknya semakin rendah nilai kecerahan maka semakin tinggi nilai TSS. Pada penelitian ini nilai kecerahan berkisar 0,31-0,783 cm, hal ini sesuai dengan hasil yang di dapat bahwa nilai kecerahan rendah dan TSS tinggi. Substrat juga berkorelasi positif terhadap TSS, kelimpahan, lamun, dan arus. Pada penelitian ini substrat yang di dapat tipe substrat berpasir, di mana bivalvia sebagai organisme dasar yang salah satu menyukai substrat berpasir. Hal ini sesuai pernyataan (Zarkasyi et al., 2016) substrat dasar merupakan salah satu faktor yang dapat mempengaruhi pola penyebaran hewan makrozobentos termasuk bivalvia, karena selain berperan sebagai tempat tinggal juga berfungsi sebagai penimbun unsur hara, tempat berkumpulnya bahan organik serta tempat perlindungan organisme dari ancaman predator. Pendistribusian sedimen biasanya sangat di tentukan oleh pasang surut, gelombang, dan debit air serta interaksi faktor biofisik kelautan lainnya.

Hasil PCA pada Gambar 8 menunjukkan bahwa dari ke-3 stasiun yang di amati memiliki kecenderungan karakteristik yang berbeda terlihat dari pengelompokkan habitat berdasarkan kesamaan ciri fisik parameter lingkungan perairan dan substrat yang di ukur. Beberapa parameter lingkungan mengelompok pada stasiun-stasiun tertentu sehingga membentuk kelompok khusus berdasarkan kemiripan habitat yang mencirikan masing-masing stasiun pengamatan.

\section{SIMPULAN DAN SARAN}

Berdasarkan hasil penelitian dapat di simpulkan bahwa:

1. Kelimpahan spesies yang di temukan sebanyak 7 (tujuh) spesies yang tergolong dalam 4 (empat) family di dominansi oleh jenis gafrarium tumidum pada 3 stasiun pengamatan. Kelimpahan tertinggi terdapat pada stasiun I dengan total kelimpahan $412 \mathrm{ind} / \mathrm{m}^{2}$.

2. Jenis Enhalus acoroides dan Cymodocea serrulata, berperan di setiap stasiun pengamatan ekosistem lamun Pantai Puding. Pada stasiun I dan III INP tertinggi yaitu jenis Cymodocea serrulata dengan masing-masing nilai 1,319 dan 0,924, sedangkan pada stasiun II nilai INP tertinggi yaitu jenis Enhalus acoroides dengan nilai 1,943.

3. Pola sebaran jenis bivalvia di Pantai Puding lebih dominan mengelompok, diantaranya jenis Anadara antiquata, Tellinia remies, Palcuna placenta, Placemen tiara dan Dosinia victoriae. Sedangkan pola sebaran seragam yaitu jenis Anomalocardia squamosa dan Gafrarium tumidum. Keterkaitan kelimpahan bivalvia dengan parameter perairan menunjukkan adanya perbedaan karakteristik setiap stasiun di lihat secara fisika kimia perairan. Stasiun I di cirikan dengan parameter kelimpahan $(-0,958)$, kecerahan

$(-0,979)$, arus $(-0,998)$, TSS $(-0,986)$, substrat $(-0,997)$ 
dan lamun (-0,996). Stasiun II di cirikan dengan parameter pH $(0,970)$, salinitas $(0,991)$ dan suhu $(0,996)$. Sedangkan stasiun III di cirikan dengan parameter DO $(-0,720)$.

\section{UCAPAN TERIMA KASIH}

Puji dan syukur penulis panjatkan atas kehadirat Allah SWT. Penulis mengucapkan terimakasih yang sebesarbesarnya kepada ibunda dan kakak tercinta. Terimkasih banyak kepada bapak Wahyu Adi, S.Pi., M.Si dan bapak Dr. Arief Febrianto, M.Si selaku pembimbing I dan II, bapak Okto Supratman, S.Pi., M.Si selaku pembimbing akademik dan dosen pembahas I, bapak Andi Gustomi, S.Pi., M.Si dan bapak M. Rizza Muftiadi, M.Si. Keluarga besar Pinguin Diving Club (PDC), keluarga besar MSP terutama MSP angkatan 14, tim puding, tim teletubbies dan ciwi-ciwi fisabillah. Terimakasih banyak kalian semua telah berperan dalam penulisan ini baik secara moril dan materil.

\section{DAFTAR PUSTAKA}

Akhrianti, I., Bengen, D.G., Setyobudiandi, I. 2014. Distribusi Spasial dan Preferensi Habitat Bivalvia di Pesisir Kecamatan Simpang Pesak Kabupaten Belitung Timur. Jurnal Ilmu dan Teknologi Kelautan Tropis. 6 (2) : 171-185.

Allifah, AN. 2018: Hubungan Kerapatan Lamun dengan Kepadatan Bivalvia di Pesisir Pantai Ori Kecamatan Pulau Haruku. Journal Biologi Science and Education. 7 (1) : 81.

Arisma S. 2017. Kelimpahan Bivalvia di Ekosistem Lamun Pulau Ketawai Kabupaten Bangka Tengah. [Skripsi]. Jurusan Manajemen Sumberdaya Perairan. Fakultas Pertanian Perikanan Dan Biologi. Universitas Bangka Belitung. Balunijuk.

Bengen, D.G. 2000. Teknik Pengambilan Contoh dan Analisis Data Biofisik Sumberdaya Pesisir. Pusat Kajian Sumberdaya Pesisir dan Lautan Fakultas Perikanan dan Ilmu Kelautan Institut Pertanian Bogor (PKSPL IPB). Jakarta. $88 \mathrm{hlm}$.

Bengen , D.G. 2002. Pedoman teknis pengenalan dan pengelolaan ekosistem mangrove. Bogor. Pusat Kajian Sumberdaya Pesisir dan Laut (PKSPL) IPB.

Brower, JE., and Zar, JH. 1998. Field and Laboratory Methods for General Ecology. The Mcgraw-Hill Companies. USA

Dharma, B. 2005. Recent and Fossil Indonesian Shells. Institut of Geological and Nuclear Sciences Lower Hutt, New Zealand: Jakarta.

Fachrul, MF. 2007. Metode Sampling Bioekologi. Bumi Aksara. Jakarta.

Herawati, P., Barus, T.A., Wahyuningsih, H. 2017. Keanekaragaman Makrozoobentos dan Hubungannya dengan Penutupan Padang Lamun (Seagrass) di Perairan Maindailing Natal Sumatera Utara. Jurnal Biosains. 3 (2).

Islami, MM. 2013: Pengaruh Suhu dan Salinitas terhadap Bivalvia. Jurnal Oseana. 38 (2) : 1-10.

Islami MM. 2014. Bioekologi Kerang Kerek Gafrarium tumidum Roding 1978 (Bivalvia: Veneridae) di Perairan Teluk Ambon Maluku. [Tesis]. Institut Pertanian Bogor.

Kementerian Negara Lingkungan Hidup No 51 tahun 2004 tentang Ketentuan Baku Mutu Air Laut untuk Biota Laut.

Kharisma, D., Adhi, C.S., Azizah, R.T.N. 2012. Kajian Ekologis Bivalvia di Perairan Semarang bagian Timur. Journal of Marine Research. 1 (2) : 216-225

Kusumaatmaja, K.P., Rudiyanti, S., 'Ain, C. 2016. Hubungan Perbedaan Kerapatan Lamun dengan Kelimpahan Epifauna di Pantai LIPI, Pulau Pari Kepulauan Seribu. Journal of Maquares. 5 (4) : 398-405.

Nurdin, J., Marusin, N., Izmiarti. Asmara, A., Deswandi, R., Marzuki, J., 2006. Kepadatan Populasi dan Pertumbuhan Kerang Darah (Anadara antiquata). (Bivalvia : Arcidae) di Teluk Sungai Pisang Kota Padang Sumatra barat. Universitas Andalas. Padang. Makara, Sains. 10 (2) : 96-101.

Odum, EP. 1993. Dasar-dasar Ekologi. Yogyakarta: Gadjah Mada University Press.

Riniatsih, I., and Munasik. 2017. Keanekaragaman Megabentos yang Berasosiasi di Ekosistem Padang Lamun Perairan Wailiti, Maumere Kabupaten Sikka, Nusa Tenggara Timur. Jurnal Kelautan Tropis 20 (1) : 55-59.

Riniatsih, I., and Widianingsih. 2007. Kelimpahan dan Pola Sebaran Kerang-kerangan di Ekosistem Padang Lamun, Perairan Jepara. Jurnal Ilmu Kelautan. 12 (1) : 53-58.

Samir, Nurgayah, W.A., Ketjulan, R. 2016. Studi Kepadatan dan Pola Distribusi di Kawasan Mangrove Desa Balimu Kecamatan Lasalimu Selatan Kabupaten Buton. Jurnal Manajemen Sumberdaya Perairan. 1 (2) : 169-181.

Setyobudiandi, I., Vitner, Y., Zairon. Kurnia, R., Susilo, S., B. 2004. Metode penarikan contoh suatu pendekatan biostatistika. PKSPL IPB. Jakarta.

Setyobudiandi, I., Sulistino. Yulianda, F., Kusmana, C., Hariyadi, S., Damar, A., Sembiring, A., Bahtiar. 2009. Sampling dan Analisis Data Perikanan dan Kelautan : Terapan Metode Pengambilan Contoh di Wilayah Pesisir dan Laut. FPIK IPB. Bogor.

Supratman O. 2015. Struktur Populasi Makanan dan Reproduksi Siput Gonggong (Strombus turturella) di Bangka Selatan, Kepulauan Bangka Belitung [Tesis]. Bandung: Institut Teknologi Bandung.

Zarkasyi, M.M., Zayadi, H., Laili, S., 2016. Diversitas Pola Distribusi Bivalvia di Zona Intertidal Daerah Pesisir Kecamatan Ujung Pangkah Kabupaten Gresik. Jurnal Ilmiah Biosainstropis (Bioscience-Tropic). 2 (1) : 1-10. 
